\title{
Understanding Push and Pull Powers on Intention to Accept for 3D Printer
}

\author{
Wen-Yu Tsao \\ Department of Information Management, \\ National Chin-Yi University of Technology, Taiwan, R. O. C. \\ No.57, Sec. 2, Zhongshan Rd., Taiping Dist., Taichung 41170, Taiwan (R.O.C.) \\ E-mail: tsaowy@ncut.edu.tw
}

Received: May 3, 2019 Accepted: May 21, 2019 Online published: May 30, 2019

doi:10.5296/ijhrs.v9i2.14863 URL: https://doi.org/10.5296/ijhrs.v9i2.14863

\begin{abstract}
With recent improvements in innovations, 3D printer is having a gradually to arouse people curiosity and meet their needs, and beginning to offer exciting and helpful new services. Of these innovations with helped people improve their live, such as miniature figurines or rebuild the wounded which is current recently. Nevertheless, are people willing to accept 3D printer with need and curiosity? There is a need to understand individuals push powers (need and curiosity) against pull power (inertia) on intention to accept and. The aim of this study was to build a new luxury acceptance model (LAM) and evaluate the effects of luxury value and pull and push powers on individual willingness to accept in 3D printer. The analytical results showed that no matter pull or push powers were the key factors for intention to accept 3D printer with online questionnaire survey. Further, findings also indicated that the links from push powers to intention to accept were stronger for the low pull power, supporting the moderating role of inertia. Implications and limitations of this study are briefly outlined.
\end{abstract}

Keywords: push and pull power, 3D printer, luxury value, curiosity, inertia, perceived need, intention to accept

\section{Introduction}

$3 \mathrm{D}$ printer is an evocative term and works well in explaining the physical appearance of an object rendered in real-time (Birtchnell et al., 2013). The 3D printing is an improved manufacturing process that creates a physical object from a digital design. There are different 3D printing technologies and materials you can print with; the model is turned into a solid three-dimensional physical object by adding material layer by layer (3D HUB, 2018). Then, the $3 \mathrm{D}$ printer generated subjects in 3-dimension which are stipulated by using high-quality 
ceramic material (Image model, 2013). The innovation, which allows consumers to order miniature figurines of their individual likenesses, is priced approximately US $\$ 2708$ (NT\$ 85,000) per set. It is expensive for the majority people in Taiwan. No wonder someone wanted to low cost lab-on-a-chip prototyping with a normal grade 3D printer (Comina et al., 2014). That pricey customized 3D printed models are popular gradually, for example, in Japan, the female wishing captured a certain moment in their lives for posterity with the model using 3D printer, especially for weddings, brides were very willing to spend money to create a likeness of themselves in their wedding finery (Wedding, 2013). Rifkin (2012) described the 3D printer as the "Third Industrial Revolution". Currently, 3D printer has been used not just for the creation of models but also in industrial applications. For instance, a team of surgeons in the UK has used 3D printing to reconstruct one side of a man's face after a traumatic motorcycle accident in which he broke his cheekbone, nose, jaw, and fractured his skull (CBS News, 2014). The related works of 3D printer are the development of patient-specific molecular imaging phantoms (Gear et al., 2014). Also Bowyer (2014) highlighted humanity's first imperfect replicator was made by 3D printer. For learners, 3D printer is an influential tool to create objects for teaching and learning in STEAM (science, technology, engineering, art, and math) education (Vanscoder, 2014). Few of related research have been found.

Based on the work of Vigneron and Johnson (2004) and Wiedmann et al. (2007) built luxury value including four characteristics: monetary value, functional value, individual value, and social value. Monetary value addresses directly as price, discount, investment, etc. For example, of the model using 3D printer, it refers to the value expressed in dollars and cents to what sacrificed to obtain the subject (e.g., Ahtola, 1984; Monroe and Krishnan, 1985; Mazumdar, 1986; Chapman, 1987; Wiedmann et al., 2007; Thomé et al., 2016). Functional value refers to the core benefits of the product alongside its value that would drive the fundamental items, product quality, distinctiveness, reliability, and durability (Sheth et al.,, 1991; Hennigs et al., 2012), like 3D printer with high quality with reliable and durable. The concept of individual value revolves around the individual positioning of the users vis-à-vis the consumption of luxury products and personal status, such as his or her values in regards to materialism (Richins and Dawson, 1992; Hennigs et al., 2015), hedonism and self-identity (Hirschman and Holbrook, 1982). Finally, social value refers to the effect perceived by the individual in terms of obtaining social recognition from the ownership of the commodity (Hennigs et al., 2012). Such as 3D printer has hedonism and showing themselves identity to obtain social recognition. Other phenomena: perceived need (Maslow, 1943) and curiosity (Moon and Kim, 2001) of intrinsic motivations have more powerful effect than extrinsic motivation to build intention to accept. Finally, an obstacle power (inertia) is the most efficient factor to stay in a stable situation (Gulati, 1995). It is a barrier to try innovation of 3D printer. $\mathrm{Li}$ et al. (2006) demonstrated the existence of switching inertia in the supplier-selection process, however, none of them explored the inertia as moderator on innovation. It is first necessary to comprehend the new mechanism with luxury value (Wiedmann et al., 2007), curiosity (Huang, 2003), and perceived need (Jeong et al., 2009) to emphasize the situations of push and pull powers when engaging in 3D printer to impact people intention to accept. 
Innovations come from human beings' needs and are what everybody encounters on a day-to-day basis for both work and entertainment. Dobrzykowski et al. (2015) found the pathways of innovation orientation for patient satisfaction in healthcare delivery. Simon and Honore Petnji Yaya (2012) improved innovation process through the integrated systems to influence customer satisfaction. The 3D printer can output whoever wants. In view of the active growth in the luxury market and the amazing 3D printer to a wider range of people need than ever, the luxury market has transformed from its traditional conspicuous life to an innovative sensibility marked by changing the way people intention to accept. In particular, people intend to accept 3D printer of considerable interest for researchers and practitioners, because innovators, innovating managers, innovating practitioners, marketers can benefit greatly from enhanced understanding of the key factors underlying 3D printer people' intention (Gear et al., 2014; Bowyer, 2014). For example, the people' monetary value, functional value, individual value, and social value of luxury value are the factors of push and pull powers to be willing to accept 3D printer. Because 3D printer is an expensive utility, in particular, the social value was an important factor during the acceptance of the innovation (i.e. mobile phone, Wei, 2001). In addition, Wiedmann et al. (2007) concluded the monetary, functional, individual, and social value of consumers' vis-à-vis luxury brands formed the basis for consumer action of multi-cultural environments. Hennigs et al. (2012) also discovered the monetary, functional, individual, and social values were the fundamental factors for consumers which those were similar among American, European, and Asian. None of them explored about 3D printer. Therefore, it is a challenge to examine the push and pull powers among users, and thus potentially serve as motivators or inhibitors of intention to accept innovation.

With regard to Chinese consumers' attitudes towards luxury brands, Zhan and He (2012) observed people' value was one psychological characteristic that drove them to buy luxury brands. Li et al. (2012) also discovered the factors including the monetary value, individual/social value that influenced the Chinese consumers' willingness to pay for luxury brand. For the human being, curiosity involves people interest in and giving attention (Moon and Kim, 2001), in other words, individual's sensory or cognitive curiosity is aroused by 3D printer. Perceived need is also viewed the construct as being caused by an "actual" state with respect to a particular need (Engel et al., 1969), that means that the 3D printer will be a necessity in people daily life. Two of above are push powers. Finally, the inertia as people unconsciously do the same action based on past experience (Kuo et al., 2013). It is also the most efficient factor to achieve objectives in a stable and reliable environment (Gulati, 1995), For example, people do the same action without thinking routinely. Will people refuse 3D printer even through push powers (curiosity and need)? There is an attempt to fill the gap of push and pull powers in the $3 \mathrm{D}$ printer. In light of the current statement of the existing research on $3 \mathrm{D}$ printer, the objective of this study is to empirically assess the push and pull powers of the intention to accept 3D printer. The remainder of the paper is systematized as follows: Section 2 reviewed the literature, hypotheses, and developed the theoretical background of this study, focusing on the model on intention to accept 3D printer with luxury (LAM). Section 3 presented the methodology and survey. Section 4 provided the analysis of the survey results. Section 5 discussed the results with the summary, contributions, 
implications, and limitations of the study.

\section{Literature Review and Hypotheses}

\section{Luxury value and curiosity, and intention to accept}

Luxury is a conceptual and a symbolic element instead of a category of products. The four kinds of value: monetary value, functional value, individual value and social value composed luxury value that strongly related to a socioeconomic context (Vickers and Renand, 2003; Eng and Bogaert, 2010) or a cross-cultural framework (Wiedmann et al., 2007). The paper defined monetary value of 3D printer as the value of a symbol expressed in dollars and cents, and to what is paid for 3D printer. In other words, people feel that the more expensive 3D printer is, the more they need. Functional value referred to the core benefit and basic utilities of $3 \mathrm{D}$ printer that drove the people to feel the quality, uniqueness, usability, reliability, and durability. Individual value referred as the personal orientation of individual on 3D printer and addresses as materialism and self-identity value. Social value referred to the degree of people being recognized in their social group(s) that they acquired conspicuousness and prestige value of 3D printer. Namely, people acquired the 3D printer to be recognized more conspicuous and popular by others, which affect the evaluation of themselves and the propensity to accept 3D printer significantly. Other constructs, such as push powers: curiosity and need, the curiosity was one of the epistemic values (Smith and Colgate, 2007). Social value is related to curiosity, novelty, and knowledge of tourists' local food consumption (Choe and Kim, 2018). A product's capacity (quality) arouses curiosity, offers novelty or satisfies a desire for functional value and may be important for consumers who are considering new experiences (Sweeney and Soutar, 2001). It relates to experienced curiosity by using new products, services or technology (Sheth and Talarzyk, 1972), they said the perceived utility aroused epistemic curiosity to determine satisfy a desire, such as about 3D printer. More recently, curiosity is the factor of the attitude among young people in the consumption of luxury products (Ferreira et al., 2017). The cost is a kind of monetary to pay that involve the time, effort, and hassle of finding and adapting to a new thing (Jones et al. 2007). Curiosity will trigger and guide intention of user behavior (Posnock, 1991). Chang et al. (2013) also found curiosity had a positive effect on continuance intention in mobile English learning for high school students using PDAs. The interactional effects of perceptual curiosity impacted on emotions and online shopping intention (Koo and Ju, 2010). The same result in middle school across the United States, the curiosity of medical marijuana ads influenced and intention and use (D'amico et al., 2015). Curiosity had a positive effect on continuance intention in mobile English learning for high school students using PDAs (Chang et al., 2013). Reio and Callahan (2004) got the curiosity was a mediator to job performance. Hill et al. (2016) found curiosity was a mediator on purchase motivation. Therefore, the author applied the luxury value in 3D printer with push and pull powers. In other words, it is generally expected that the people felt the monetary value, functional value, individual value, and social value of luxury value should have a positive impact on curiosity, which in turn should influence their intention to accept 3D printer. This paper proposed the following hypotheses: 
$\mathrm{H}_{1 \mathrm{a}, \mathrm{b}, \mathrm{c}, \mathrm{d}}$ : people' judgments the monetary, functional, individual, and social value of luxury value regarding $3 \mathrm{D}$ printer will have positive effects on their curiosity.

$\mathrm{H}_{3}$ : people' curiosity regarding $3 \mathrm{D}$ printer will have a positive effect on intention to accept.

$\mathrm{H}_{7}$ : people feel that the relationships from the monetary, functional, individual, and social value of luxury value to intention to try through curiosity.

Luxury value, perceived need, and intention to accept

The material need is a necessary for daily life, it also have positive relationship with people luxury values (Wiedmann et al., 2007). It is an especially important factor within a specific context, such as 3D printer. Some researches of need recognition view the construct as being caused by an "actual" state with respect to a particular need (Engel et al., 1969). The values vary across people and reflect the influence perceived need in a cross-cultural framework (Wiedmann et al., 2007; Jeong et al., 2009). In China, the more expensive (monetary) product is, the more people need (Zhan and He, 2012). Materialism may influence satisfied consumer what the situation is meet with his or her need (Richins, 1987). The functional value also strengthens the individual's need for uniqueness (Kuo et al., 2013). The need for uniqueness has the relationship with the luxury brand value and brand identification (Hyun and Kim, 2015). A product or a service, such as luxury 3D printer, is designed to perform a particular function to satisfy consumer needs. Values serve as socially acceptable (Hitlin and Piliavin, 2004), in other words, people think the 3D printer is more expensive, they will be accepted by the others. Perceived need positively affected purchase intention in marketing applications (Warshaw, 1980). In Taiwan, Teng et al. (2009) agreed that users' perceived need positively affects behavioral intentions of third-generation (3G) mobile phones. Jeong et al. (2009) also found that users' perceived need predicted behavioral intentions on mobile-RFID services. Consumers purchase luxury brands mainly for self-expression that are primarily driven by needs (Zhan and He, 2012). When users perceive themselves as having a high need for a product/service, they will become more eager to buy. In other words, people feel that monetary value, functional value, individual value, and social value compose the luxury value about 3D printer that will impact on intention to accept. Bush (1996) said need was a mediator for negotiators. Also, Riskin (1994) got need was a mediator on strategies and techniques. When an innovation is generally perceived to need, potential people tend to exhibit a higher intention to accept (Sun and Zhang, 2006). In Japan, consumers' need for uniqueness effects on their purchase intention (Shen et al., 2014; Knight and Young Kim, 2007). In the same vein, it is generally expected that the people felt the monetary value, functional value, individual value, and social value of luxury value should have a deep positive impact on perceived need, which in turn should influence their intention to accept 3D printer. Therefore, this paper proposed the following hypotheses:

$\mathrm{H}_{2 \mathrm{a}, \mathrm{b}, \mathrm{c}, \mathrm{d}}$ : people' judgments the monetary value, functional value, individual value and social value of luxury value regarding 3D printer will have positive effects on their perceptions of need.

$\mathrm{H}_{4}$ : people' judgments of need regarding 3D printer will have a positive effect on intention to 
accept.

$\mathrm{H}_{8}$ : people feel that the relationships from the monetary, functional, individual, and social value of luxury value to intention to try through need.

Inertia and Intention to Accept

Inertia is the most efficient factor to achieve objectives in a stable and reliable environment (Gulati, 1995). According to Oliver (1999) and Kuo et al. (2013) defined the inertia as people unconsciously do the same action based on past experience to avoid change. The inertia tended to influence customers to re-patronize a certain store (Solomon, 2007), do goal-direct behaviors (Zeelenberg and Pieters, 2004), repeat unconscious decision (Vigneron and Johnson, 2004), or be accustomed by habit (Bozzo, 2002). Therefore, when people have the high level of inertia, I call it pull power; they tend to repeat the certain action without changing (Colgate and Lang, 2001; Yanamandram and White, 2010). The inertia of people may negatively affect their perceptions of a newly system (Jones et al., 2000). Generally, when an innovation is coming, people are habit to use the current system and unwilling to use the new one. Other studies also agreed that inertia could act as an inhibitor to changing, which implies this factor is a psychological barrier for people to accept the new (Jones et al., 2000). In other words, the more frequently people do an action routinely, the more comfortable they feel. For particular goods or service provider, consumers get used to the past consumption to avoid alteration (Solomon, 2007). In the previous researches also indicated that the effect of satisfaction on such intentions could be reduced when inertia is low (Bell et al., 2005; Jeong et al., 2009). Kuo et al. (2013) also got consumer inertia was more influential than satisfaction on repeat-purchase intention. The inertia on customer satisfaction and loyalty has moderating effect (Anderson and Srinivasan, 2003). In other words, customers had a stronger feeling of inertia would decrease relationship between satisfaction and loyalty. Han et al. (2011) tested the inertia had moderated effects on both commitment and intention to loyalty to inform firms' success. Also in a new system, inertia moderates the relationship between subjective norm and intention on new system acceptance (Liu et al., 2007). According to the above discussions, inertia plays a key pull effect in forming curiosity and perceived need to intentions to accept. Therefore, this paper proposed the following hypotheses:

$\mathrm{H}_{5}$. When inertia is higher, the positive relationship between curiosity and intention to accept is weaker.

$\mathrm{H}_{6}$. When inertia is higher, the positive relationship between perceived need to intention to accept is weaker.

Therefore, Inertia is pull power for 3D printer. The relationships among these constructs showed in figure 1 . 


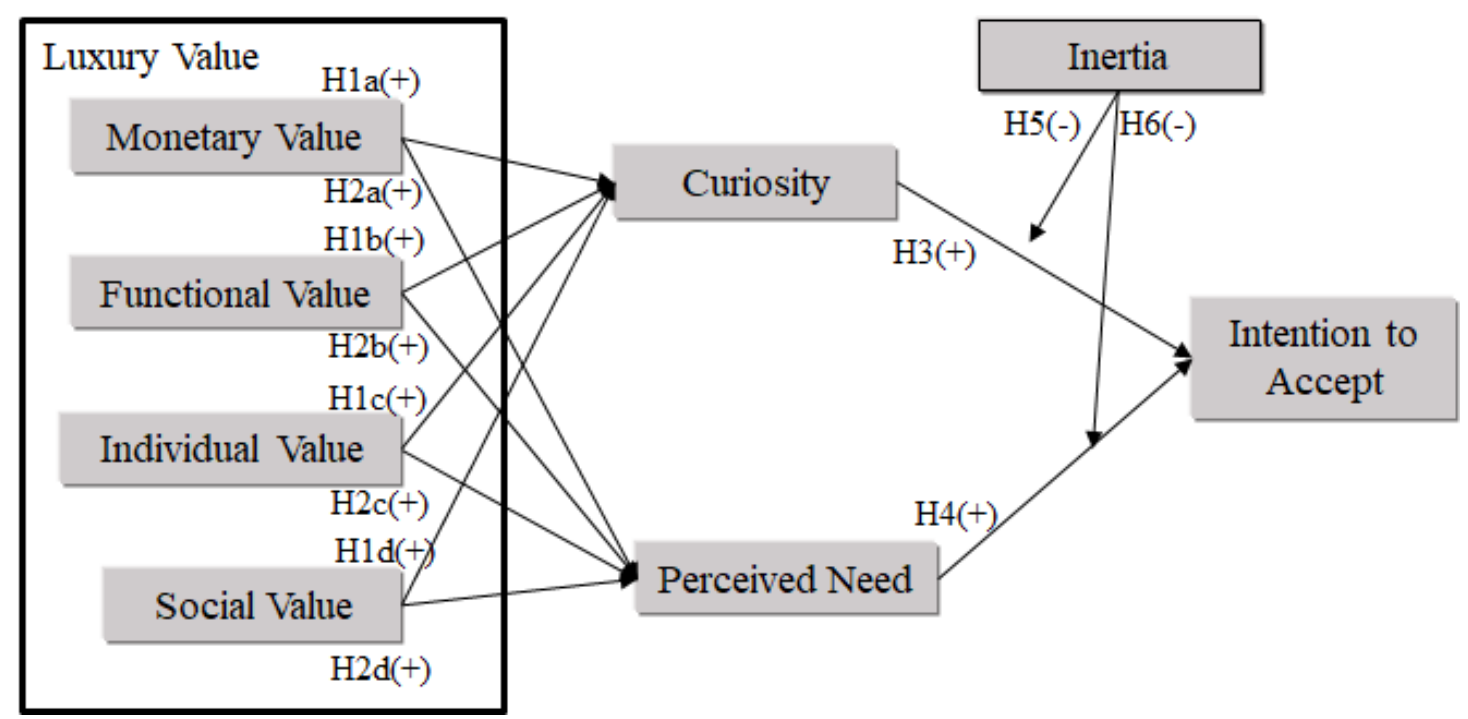

Figure 1. Research model

\section{Methodology}

Settings and Design:

A cross-sectional survey of 350 users in Taiwan took ten months through visiting schools, colleges, businesses, research organizations, Internet cafes, e-mail surveys and explanations in Taiwan from 1st January to 31st October in 2016.

\section{Survey instrument}

The research adopted the questionnaire to collect data. Demographic information included the gender, age, occupation, income, education, and situation. The items of the eight constructs in this questionnaire were adopted and modified from qualified studies to fit the scope of this study. Participants indicated the degree to which they agreed with statements using a 7-point Likert-type scale (ranged from 1-strongly disagree to 6-strongly agree) without no comment. Most of the items used to measure the constructs in this study are altered from previous studies in order to ensure content validity. This study employed a modified version of the scale developed by Deng et al. (2010), using three items for monetary value and four items for functional, individual, and social values to evaluate people' perceptions of the luxury value about the model knowing 3D printer. The curiosity was adopted and modified each the three items from Moon and Kim (2001) scale for to indicate the degree of people' sensory or cognitive curiosity were aroused by knowing 3D printer. The study also employed perceived need and intention to accept from the modified three items of the scale used by Teng et al. (2009) scale for to indicate the degree of need and willing to accept the 3D printer. Finally, the moderator variable: inertia was adopted and modified Lee and Neale (2012) and Polites and Karahannam (2012), including six items to evaluate the degree of people attitudinal propensity to maintain the current state. The survey items are shown in the Appendix.

\section{Pretest and pilot test}

After I developed the preliminary questionnaire, I conducted pretest heard or seen 3D printer 
25 people for their feedback on the questionnaire and revised the questions to assess logical consistencies, ease to understand, the sequential items, and the relevant questions (Oksenberg et al., 1991). Among them are a few professors and employees, each with significant expertise in the study of $3 \mathrm{D}$ printer. A few modifications suggested by the users were incorporated into the revised instrument. For example, "At present, I need innovations" changed to "At present, I need 3D printer". A pilot test involved 50 respondents who are heavy high technology services users. The instrument resulted in a significant degree of refinement and restructuring of the survey instrument to establish the initial face validity and internal validity of the measures (Nunnally, 1978).

Data collection

To ensure that the measured beliefs were based on the saw or heard the 3D printer were included in this analysis. Among the 900 questionnaires spread through mail and social media (FB, LINE, and so on), approximately $38.9 \%$ of the collected questionnaires were usable. Finally, 350 questionnaires were eventually used for this empirical analysis.

The demographic profile of the 350 respondents is shown in Table 1. With regard to gender, females presented $(58.3 \%)$ over males $(41.7 \%)$. With regard to education, the majority were colleges (about $48.6 \%$ ) and graduate $(31.1 \%)$. Among these respondents, respondents represented industries in Taiwan, including students $(31.9 \%)$, employee in information technology $(16.5 \%)$, telecommunication $(14.1 \%)$, service $(9.0 \%)$, manufacturing $(7.3 \%)$, researcher $(6.1 \%)$, manager $(4.7 \%)$, housewife $(3.8 \%)$, retiree $(2.8 \%)$, and the rest $(3.8 \%)$. Monthly income was less than NT $\$ 10,000$ for $28.0 \%$ of respondents, the reason maybe the respondents are students $(27.1 \%)$. The rest income showed as NT $\$ 10,001 \sim \mathrm{NT} \$ 32,000$ (41.8\%), NT\$32,001 NT\$50,000 (15.5\%), and NT\$50,001 or more (14.8\%) which these respondents are reluctant to try $3 \mathrm{D}$ printer which are too expensive to them.

Reliability and validity

The items of constructs were developed through general and refined validation. Data reliability, convergent validity, and discriminated validity were examined. The study directed factor analyses of eight constructs with twenty-nine items with the mean and standard error to examine the validity of this measurement. With principal component analysis and varimax rotation, twenty-six items resulted in eight constructs with eigenvalues higher 1.0; these factors accounted for $70.939 \%$ of the total variance. The reliability of the eight constructs ranged from 0.700 to 0.931 that should exceed 0.700 (Nunnally, 1978; Sethi and King, 1994). All constructs passed the reliability test except the first item of individual. I also used composite reliability (CR) which to measure the internal consistency that greater than 0.7 , the average variance extracted (AVE) which to measure the variance of the measurement error that greater than 0.5 to test convergent validity and correlation to test discriminated validity, showed in table 2. The AVE of individual is below 0.5, according Hair et al. (1995), the AVE of three or four constructs can reach 0.50 in the paper, and the AVE of other constructs has at least 0.30 or 0.40 which is generally acceptable. Therefore, the individual included. Finally, discriminated validity were examined with correlation, the square root of each constructor's AVE was larger than its corresponding correlation coefficient, detail showed in table 3, which 
showed that it had good discriminant validity (Fornell and Larcker, 1981).

Hypotheses testing

To make great efforts to determine the effects of luxury value, curiosity, perceived need, and intention to accept moderated by inertia about 3D printer, I conducted PROCESS which is a computational tool for path analysis-based moderation and mediation analysis, as well as their combination as a "conditional process model". According to Hayes and Preacher (2014) and Hayes (2015), PROCESS is a calculation tool for path-analysis-based mediation and mediation analysis and proposes models constructed by 92 model-validation researchers. In this study, I used the 15th model in Process 3.0, to identify the mediator and moderator effects. I then used a bootstrapping technique (Preacher and Hayes, 2004) to test these effects. Using this methodology resampled the data 5000 times to estimate the confidence intervals of the mediated effects. I interpreted the significance of the bootstrap data by determining whether zero was contained within the 95\% confidence interval (CI), where zero is considered to be non-significant. The results indicate that respondents felt that the functional and individual value significantly influenced curiosity $(\beta=0.183 ; \mathrm{t}=3.732, \mathrm{p}<0.001 ; \beta=$ $0.270 ; \mathrm{t}=6.422, \mathrm{p}<0.001 ; \mathrm{R} 2=0.163 ; \mathrm{F}=27.802 * * *)$, and the lower limit confidence interval (LLCI=0.087 and 0.188) and upper limit confidence interval (ULCI $=0.279$ and 0.353) do not include zero as representing significance. In other words, the respondents thought fundamental items to show their personal status with high quality increased their curiosity. As such, hypotheses $1 \mathrm{~b}$ and $1 \mathrm{c}$ were supported. The respondents feel that the monetary, functional, individual, and social value influenced their need $(\beta=0.105 ; \mathrm{t}=2.853, \mathrm{p}<0.001$; $\beta=0.466 ; \mathrm{t}=11.780, \mathrm{p}<0.001 ; \beta=0.178 ; \mathrm{t}=5.248, \mathrm{p}<0.001 ; \beta=-0.075 ; \mathrm{t}=-2.686, \mathrm{p}<$ $\left.0.001 ; \mathrm{R}^{2}=0382 ; \mathrm{F}=88.348 * * *\right)$ and the UUCI $(0.033,0.388,0.112$, and -0.130$)$ and ULCI $(0.177,0.544,0.245$, and -0.020$)$ also do not include zero respectively, as shown in Table 4. Evidently, respondents' perceptions of the quality, the value of $3 \mathrm{D}$ printer to show their personal status and the effect of 3D printer to obtain social recognition generally led to their need. Therefore, hypotheses $2 \mathrm{a}, 2 \mathrm{~b}, 2 \mathrm{c}$, and $2 \mathrm{~d}$ were supported. Finally, need of $3 \mathrm{D}$ printer is a promoter of the tendency to use $3 \mathrm{D}$ printer $\left(\beta=0.488 ; \mathrm{t}=3.595, \mathrm{p}<0.001 ; \mathrm{R}^{2}=0.307 ; \mathrm{F}\right.$ $=24.979 * * *)$, and the lower limit confidence interval (LLCI=0.206) and upper limit confidence interval (ULCI=0.770) which do not include zero as representing significance. These results demonstrate that the respondents' intention to accept 3D printer is significantly affected by their feelings regarding only need.

Next, I assessed inertia as a moderator (a pull effect) with respect to the intention to accept. I found two non-significant interactions (curiosityXineria and needXinertia) for the intention to accept $(\beta=-0.045, \mathrm{t}=-1.097, \mathrm{p}>0.05)$ and $(\beta=-0.152, \mathrm{t}=-3.794, \mathrm{p}<0.05)$, and the lower limit confidence interval (LLCI $=-0.127$ and -0.231) and upper limit confidence interval (ULCI $=0.036$ and -0.073 ) which the former include zero and the latter did not include zero as representing only the latter significance. Therefore, there is only one moderating effect from need on intention to accept. From Figure 2, it is seen that inertia is not an obstacle of the intention to accept 3D printer when people became highly curiosity. In the same vein, the inertia is a hurdle of the intention to accept 3D printer when people became highly need, shown in Figure 3. Therefore, inertia is a pull effect to prevent the push effect (need) on 


\section{Macrothink}

intention to accept. This finding implied that people with low inertia those who perceived need are more likely to form acceptance intentions.

Finally, as a further step, I evaluated the curiosity and need would be mediators for monetary, functional, individual, and social value on the intention to accept. I evaluated that mediation tests of curiosity found both the direct effects of functional and individual for curiosity and need were ( $\beta=0.440$ with CI: 0.108 to 0.239 in $95 \%$ ) on the tendency to accept. The indirect effects of functional and individual for curiosity were $(\beta=-0.217$ with CI: -0.366 to -0.074 ; $\beta=0.388$ with CI: 0.106 to 0.660 in $95 \%$ ). Next, I evaluated the need for the indirect effects of functional and individual ( $\beta=-0.125$ with $\mathrm{CI}$ : -0.144 to $-0.033 ; \beta=0.424$ with $\mathrm{CI}$ : 0.380 to 0.469 in $95 \%$ ) on the tendency to accept. Thus, the bootstrapping results proved that curiosity and need had partial mediating effects from functional and individual value on intention to accept 3D printer.

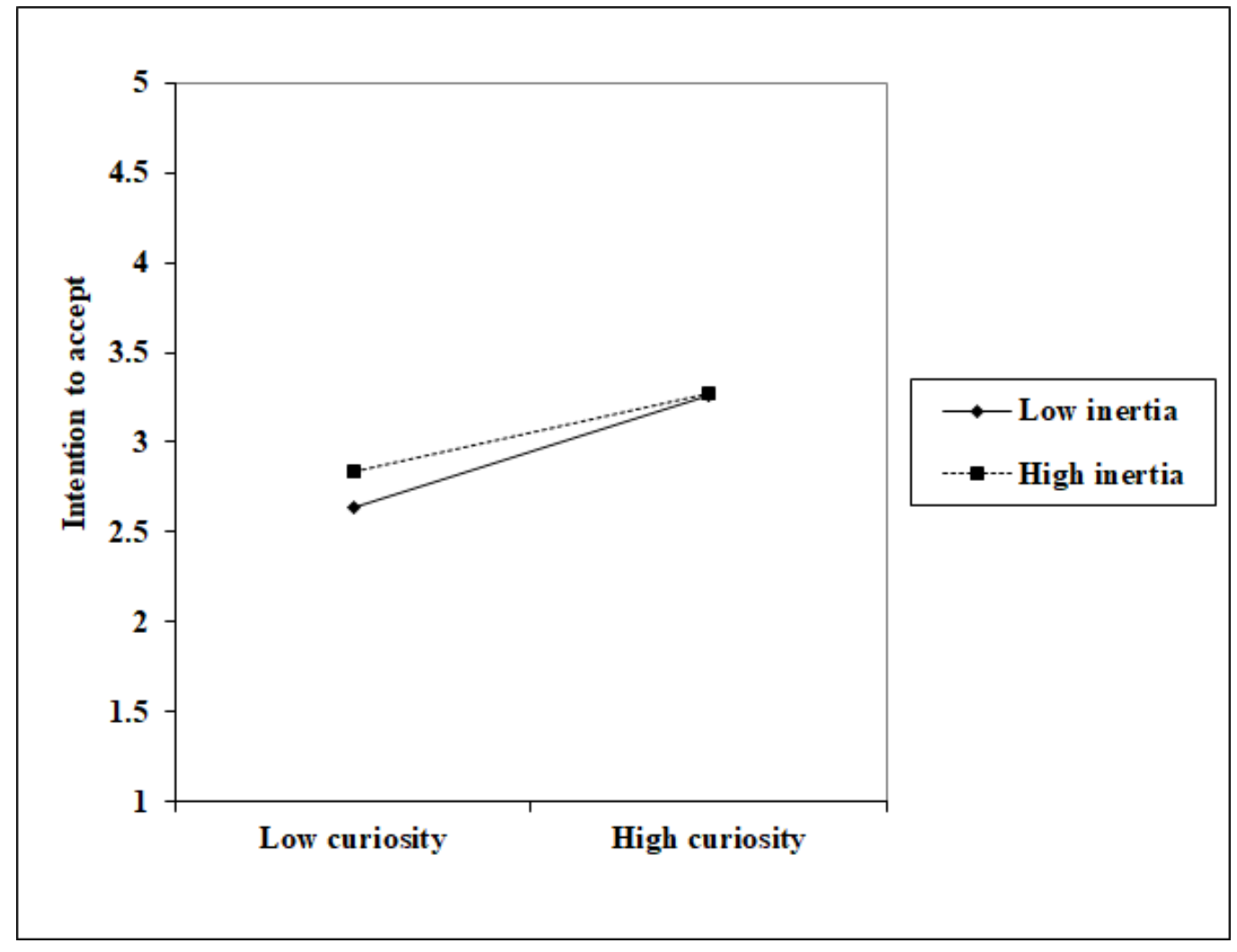

Figure 2. Moderating effect of people' inertia between curiosity and intention to accept 


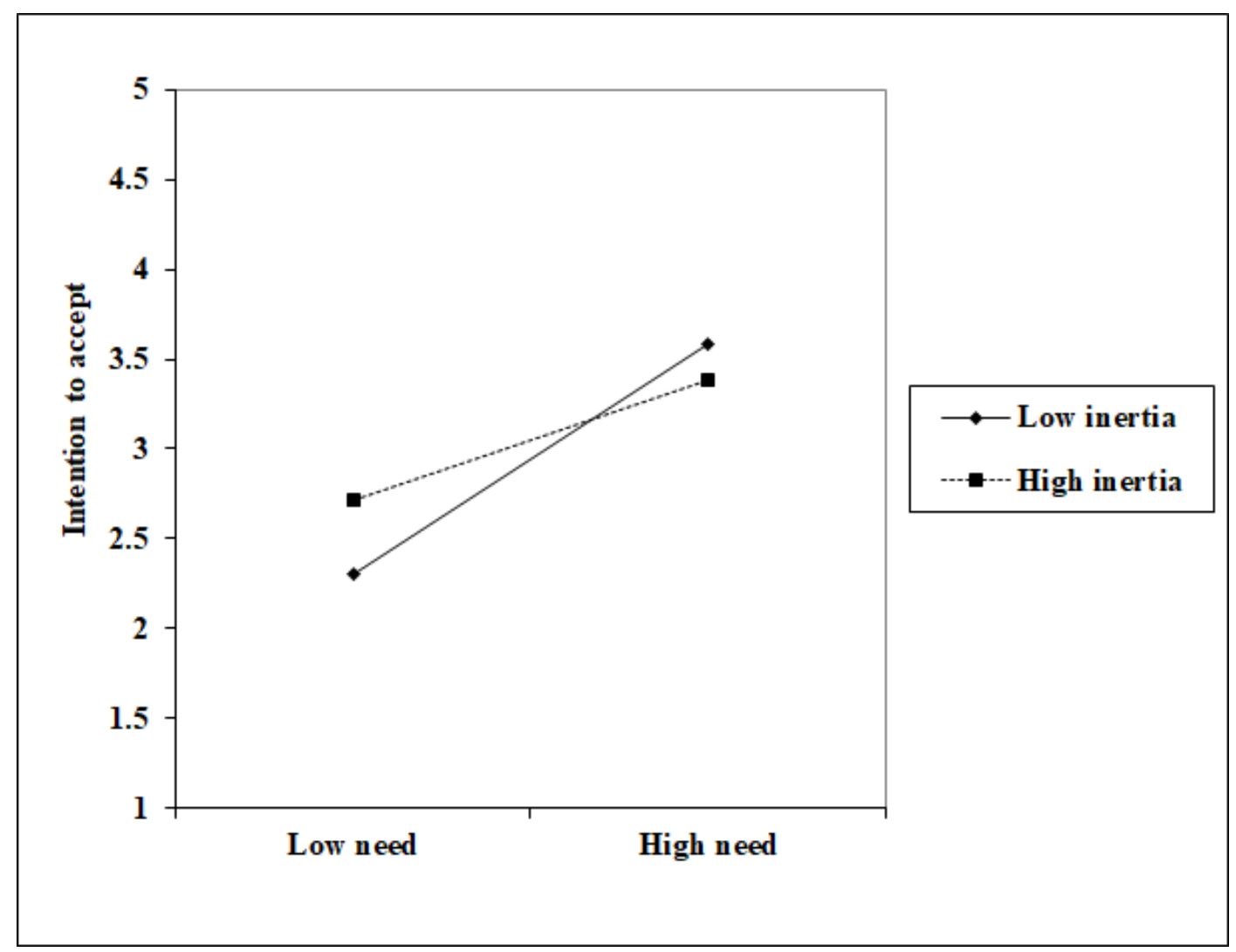

Figure 3. Moderating effect of people' inertia between need and intention to accept

\section{Discussion and Conclusion}

The main purpose of this study was to determine the pull or push powers that affect the intention to accept 3D printer. To achieve this goal, a research model was proposed which consisted of four characteristics of luxury value, two push powers (curiosity and perceived need), one pull power (inertia), and one dependent variable (the intention to accept) to apply 3D printer. The key contributions of this study are as follows. First, this study successfully applied luxury value in the innovation, such as 3D printer with individual perception push powers (curiosity and perceived need) moderated by pull power (inertia) mostly; however, it was ignored in the previous studies. The validated instrument will be useful to researchers in further developing and refining innovations research models, as well as to managers in employing actual innovations to be more acceptable intention. The results of empirical analysis showed that push powers (curiosity and perceived need) were determined to be significant antecedents of the intention to accept for 3D printer. People thought functional and individual value of luxury value is critical determinants of the curiosity of $3 \mathrm{D}$ printer. The individual value has the greatest power on people curiosity of feeling than others do. As for the perceived need, all value of luxury value impact on the need. That means people do concern the quality of functional value that they have to pay attention for innovation.

The in-depth analysis of 3D printer, these results provide priceless information on the push powers (curiosity and perceived need) for people intention to accept with pull power (inertia). All these give us some insight into points we need to encourage innovation. From the 
theoretical implications, the luxury value is a conceptual and symbolic concept which strongly related to socioeconomic context (Eng and Bogaert, 2010). The inertia was the negative effect of technological innovations to be accepted (Mokyr, 2000). It will form push and pull powers. However, very little research focuses on people luxury value and intention to accept the 3D printer with push and pull powers. The paper built successfully the intention to accept model with luxury value (LAM) with both push powers (curiosity and perceived need) and pull power (inertia). With difference of the previous studies found the pull power (inertia) as a psychological barrier to changing (Jones et al., 2000; Colgate and Lang, 2001; Huang, 2003; Yanamandram and White, 2010). Also the paper investigated the pull power (inertia) was still an obstacle to reduce the intention to accept 3D printer. People interacted in sometimes surprising ways with two levels that were curiosity and need driven (Marburger, 2011). The innovation should be designed and developed the valuable push powers (curiosity and perceived need) that people want to try without hesitate. From managerial implications, the LAM succeeded in predicting beyond the inside of innovation itself and explained how people perceptions luxury value of innovation to promote their ace intention to accept with reducing pull power (inertia) on both push powers (curiosity and need). The push driven (need) connecting luxury value with intention to accept 3D printer was the strongest path to innovators to create innovations with quality, uniqueness, usability, and requirement to come across boundaries. Comprehensive promoting innovations of luxury value not only have the quality, uniqueness, usability, and requirement, the innovating managers should know people' feeling fun and need but also people can show self-identity and be recognized among their own social group(s). Based on this, innovating practitioners should execute innovations with luxury value, such as high expensive, quality, uniqueness, and self-identity to reflect people vanity. From a market positioning point of view, the providers need to apply different promote strategies depending on the people situations and dispersion of 3D printer. For example, the injured or people just for fun is quite different need, the formers need high quality product and the latter need normal one. Finally, researchers could identify and apply the specific luxury value of innovation, such as cell phone or mash-up service with both enjoyable and required.

There are still some limitations in this study. First of all, making possible efforts were made to explore the relationships among those constructs; considerable work is still required for longitudinal study to know people push powers (curiosity and perceived need) and pull power (inertia). Second, the curiosity and need had not been supported in this paper which needs to explore further. The satisfaction related with luxury value in luxury-hotel restaurants (Wu and Liang, 2009); this study would add the satisfaction for 3D printer as factor of intention to accept in the future. Finally, future studies should consider measuring actual use, to investigate usage of the innovation more precisely.

\section{Reference}

3D HUBS. (2018). What is 3D printing? The definitive guide. https://doi.org/10.1016/B978-0-12-803917-5.00002-X 
Ahtola, O. T. (1984), Price as a 'Give' component in an exchange theoretic multicomponent model. Advances in Consumer Research, 11(1), 623-636.

Anderson, R. E., \& Srinivasan, S. S. (2003). E-satisfaction and e-loyalty: A contingency framework. Psychology \& marketing, 20(2), 123-138. https://doi.org/10.1002/mar.10063

Bell, S. J., Auh, S., \& Smalley, K. (2005). Customer relationship dynamics: Service quality and customer loyalty in the context of varying levels of customer expertise and switching costs. Journal of the Academy of Marketing Science, 33(2), 169-183. https://doi.org/10.1177/0092070304269111

Birtchnell, T., Urry, J., Cook, C., \& Curry, A. (2013). Freight Miles: The Impact of 3D Printing on Transport and Society, E.S.R.C. of Lancaster University.

Bowyer, A. (2014). 3D printing and humanity's first imperfect replicator. 3D printing and additive manufacturing, 1(1), 4-5. https://doi.org/10.1089/3dp.2013.0003

Bozzo, C. (2002). Understanding inertia in an industrial context. Journal of Customer Behaviour, 1(3), 335-355. https://doi.org/10.1362/147539202764441083

Bush, R. A. B. (1996). What do we need a mediator for: Mediation's value-added for negotiators. Ohio St. J. on Disp. Resol., 12(1), 1-36.

CBS News. (2014). Man's face reconstructed with 3D printer after motorcycle accident. https://www.cbsnews.com/news/mans-face-reconstructed-with-3d-printer-after-motorcycle-ac cident/.access time 2018/12/11

Chang, C. C., Tseng, K. H., Liang, C., \& Yan, C. F. (2013). The influence of perceived convenience and curiosity on continuance intention in mobile English learning for high school students using PDAs. Technology, Pedagogy and Education, 22(3), 373-386. https://doi.org/10.1080/1475939X.2013.802991

Chapman, J. D. (1987). The impact of discounts on subjective product rvaluations, Doctoral dissertation, Department of Marketing, Virginia Polytechnic Institute and State University, Blacksburg, VA.

Choe, J. Y. J., \& Kim, S. S. (2018). Effects of tourists' local food consumption value on attitude, food destination image, and behavioral intention. International Journal of Hospitality Management, 71, 1-10. https://doi.org/10.1016/j.ijhm.2017.11.007

Colgate, M., \& Lang, B. (2001). Switching barriers in consumer markets: An investigation of the financial services industry. Journal of consumer marketing, 18(4), 332-347. https://doi.org/10.1108/07363760110393001

Comina, G., Suska, A., \& Filippini, D. (2014). Low cost lab-on-a-chip prototyping with a consumer grade 3D printer. Lab on a chip, 14(16), 2978-2982. https://doi.org/10.1039/C4LC00394B

D'amico, E. J., Miles, J. N., \& Tucker, J. S. (2015). Gateway to curiosity: Medical Marijuana ads and intention and use during middle school. Psychology of Addictive Behaviors, 29(3), 
613-619. https://doi.org/10.1037/adb0000094

Deng, Z., Lu, Y., Wei, K. K., \& Zhang, J. (2010). Understanding customer satisfaction and loyalty: An empirical study of mobile instant messages in China. International Journal of Information Management, 30(4), 289-300. https://doi.org/10.1016/j.ijinfomgt.2009.10.001

Detekt (2014) Chang Gung hospital reconstructs woman' jaw from Hong Kong, http://www.detekt.com.tw/index.php/industry-news-2/item/186-2013-12-30-08-20-01, access time 2018/12/19.

Dobrzykowski, D. D., Callaway, S. K., \& Vonderembse, M. A. (2015). Examining pathways from innovation orientation to patient satisfaction: A relational view of healthcare delivery. Decision Sciences, 46(5), 863-899. https://doi.org/10.1111/deci.12161

Eng, T. Y., \& Bogaert, J. (2010). Psychological and cultural insights into consumption of luxury western brands in India. Journal of Customer Behavior, 9(1), 55-75. https://doi.org/10.1362/147539210X497620

Engel, J. F., Kegerreis, R. J., \& Blackwell, R. D. (1969). Word-of-mouth communication by the innovator. Journal of Marketing, 33(3), 15-19. https://doi.org/10.1177/002224296903300303

Ferreira, M. Â., da Silva Tamashiro, H. R., \& Braga, S. S. (2017). An exploratory study on the dimensions that motivate the attitudes of young consumers to the consumption of luxury products. Mediterranean Journal of Social Sciences, 8(4), 87-96. https://doi.org/10.1515/mjss-2017-0008

Fornell, C., \& Larcker, D. F. (1981). Evaluating structural equation models with unobservable variables and measurement error. Journal of Marketing Research, 18(1), 39-50. https://doi.org/10.1177/002224378101800104

Gear, J. I., Long, C., Rushforth, D., Chittenden, S. J., Cummings, C., \& Flux, G. D. (2014). Development of patient-specific molecular imaging phantoms using a 3D printer. Medical physics, 41(8), 1-3. https://doi.org/10.1118/1.4887854

Gulati, R. J. (1995). Determination of Mechanical Properties of the Human Fingerpad, in Vivo, Using a Tactile Stimulator, MS thesis, Boston University, Boston, MA.

Hair, J. F., Anderson, R. E., Tatham, R. L., \& Black, W. C. (1995). Multivariate data analysis with readings (4th ed.). London: Prentice-Hall.

Han, H., Kim, Y., \& Kim, E. K. (2011). Cognitive, affective, conative, and action loyalty: Testing the impact of inertia. International Journal of Hospitality Management, 30(4), 1008-1019. https://doi.org/10.1016/j.ijhm.2011.03.006

Hayes, A. F. (2015). An index and test of linear moderated mediation. Multivariate behavioral research, 50(1), 1-22. https://doi.org/10.1080/00273171.2014.962683 


\section{Ml Macrothink}

International Journal of Human Resource Studies

ISSN 2162-3058 2019, Vol. 9, No. 2

Hayes, A. F., \& Preacher, K. J. (2014). Statistical mediation analysis with a multicategorical independent variable. British Journal of Mathematical and Statistical Psychology, 67(3), 451-470. https://doi.org/10.1111/bmsp.12028

Hennigs, N., Wiedmann, K. P., Klarmann, C., \& Behrens, S. (2015). The complexity of value in the luxury industry: From consumers' individual value perception to luxury consumption. International Journal of Retail \& Distribution Management, 43(10/11), 922-939. https://doi.org/10.1108/IJRDM-07-2014-0087

Hennigs, N., Wiedmann, K. P., Klarmann, C., Strehlau, S., Godey, B., Pederzoli, D., \& Oh, H. (2012). What is the value of luxury? A cross-cultural consumer perspective. Psychology \& Marketing, 29(12), 1018-1034. https://doi.org/10.1002/mar.20583

Hill, K. M., Fombelle, P. W., \& Sirianni, N. J. (2016). Shopping under the influence of curiosity: How retailers use mystery to drive purchase motivation. Journal of Business Research, 69(3), 1028-1034. https://doi.org/10.1016/j.jbusres.2015.08.015

Hitlin, S., \& Piliavin, J. A. (2004). Values: Reviving a dormant concept. Annual Review of Sociology, 30, 359-393. https://doi.org/10.1146/annurev.soc.30.012703.110640

Holbrook, M. B., \& Hirschman, E. C. (1982). The experiential aspects of consumption: Consumer fantasies, feelings, and fun. Journal of consumer research, 9(2), 132-140. https://doi.org/10.1086/208906

Huang, M. H. (2003). Designing website attributes to induce experiential encounters. $\begin{array}{llll}\text { Computers in Human } & \text { Behavior, } & \text { 19(4), }\end{array}$ https://doi.org/10.1016/S0747-5632(02)00080-8

Hyun, S. S., \& Kim, M. G. (2015). Negative effects of perceived crowding on travelers' identification with cruise brand. Journal of Travel \& Tourism Marketing, 32(3), 241-259. https://doi.org/10.1080/10548408.2014.892469

Image model. (2013). 3D printing yourself UK supermarket alternative service. http://hk.epochtimes.com/b5/13/10/22/185784.htm, access time 2018/10/9.

Jeong, N., Yoo, Y., \& Heo, T. Y. (2009). Moderating effect of personal innovativeness on mobile-RFID services: Based on warshaw's purchase intention model. Technological Forecasting \& Social Change, 76(1), 154-164. https://doi.org/10.1016/j.techfore.2008.08.007

Jones, M. A., Mothersbaugh, D. L., \& Beatty, S. E. (2000). Switching barriers and repurchase intentions in services. Journal of retailing, 76(2), 259-274. https://doi.org/10.1016/S0022-4359(00)00024-5

Jones, M. A., Reynolds, K. E., Mothersbaugh, D. L., \& Beatty, S. E. (2007). The positive and negative effects of switching costs on relational outcomes. Journal of Service Research, 9(4), 335-355. https://doi.org/10.1177/1094670507299382 
Knight, D. K., \& Young, K. E. (2007). Japanese consumers' need for uniqueness: Effects on brand perceptions and purchase intention. Journal of Fashion Marketing and Management: An International Journal, 11(2), 270-280. https://doi.org/10.1108/13612020710751428

Koo, D. M., \& Ju, S. H. (2010). The interactional effects of atmospherics and perceptual curiosity on emotions and online shopping intention. Computers in Human Behavior, 26(3), 377-388. https://doi.org/10.1016/j.chb.2009.11.009

Kuo, Y. F., Hu, T. L., \& Yang, S. C. (2013). Effects of inertia and satisfaction in female online shoppers on repeat-purchase intention: The moderating roles of word-of-mouth and alternative attraction. Managing Service Quality: An International Journal, 23(3), 168-187. https://doi.org/10.1108/09604521311312219

Lee, R., \& Neale, L. (2012). Interactions and consequences of inertia and switching costs. Journal of services marketing, 26(5), 365-374. https://doi.org/10.1108/08876041211245281

Li, G., Li, G., \& Kambele, Z. (2012). Luxury fashion brand consumers in China: Perceived value, fashion lifestyle, and willingness to pay. Journal of Business Research, 65(10), 1516-1522. https://doi.org/10.1016/j.jbusres.2011.10.019

Li, S., Madhok, A., Plaschka, G., \& Verma, R. (2006). Supplier-switching inertia and competitive asymmetry: A demand-side perspective. Decision Sciences, 37(4), 547-576. https://doi.org/10.1111/j.1540-5414.2006.00138.x

Liu, T. C., Wu, L. W., \& Hung, C. T. (2007). The effects of inertia and switching barriers on satisfaction-retention relationship: A case of financial service industries. Journal of Management, 24(6), 671-687.

Marburger, J. H. (2011). Science, technology and innovation in a 21st century context. Policy Sciences, 44(3), 209-213. https://doi.org/10.1007/s11077-011-9137-3

Maslow, A. H. (1943). A theory of human motivation. Psychological review, 50(4), 370-396. https://doi.org/10.1037/h0054346

Mazumdar, T. (1986) Experimental investigation of the psychological determinants of buyers' price awareness and a comparative assessment of methodologies for retrieving price information from memory. Working paper. Virginia Polytechnic Institute and State University.

Mokyr, J. (2000). Innovation and its enemies: The economic and political roots of technological inertia. A Not-So-Dismal Science: A Broader View of Economics, 61-91. https://doi.org/10.1093/0198294905.003.0003

Monroe, K. B., \& Krishnan, R. (1985). The effect of price on subjective product evaluations. Perceived quality, 1, 209-232.

Moon, J. W., \& Kim, Y. G. (2001). Extending the TAM for a world-wide-web context. Information \& Management, 38, 217-230. https://doi.org/10.1016/S0378-7206(00)00061-6

Nunnally, J. C. (1978). Psychometric Theory, McGraw-Hill, New York. 
Oksenberg, L., Cannell, C., \& Kalton, G. (1991). New strategies for pretesting survey questions. Journal of official statistics, 7(3), 349-365.

Oliver, R. L. (1999). Whence consumer loyalty? The Journal of Marketing, 63, 33-44. https://doi.org/10.2307/1252099

Polites, G. L., \& Karahanna, E. (2012). Shackled to the status quo: The inhibiting effects of incumbent system habit, switching costs, and inertia on new system acceptance. MIS quarterly, 36(1), 21-42. https://doi.org/10.2307/41410404

Posnock, R. (1991). The trial of curiosity. Henry James, William James, and the Challenge of Modernity, Oxford University Press.

Preacher, K. J., \& Hayes, A. F. (2004). SPSS and SAS procedures for estimating indirect effects in simple mediation models. Behavior Research Methods, Instruments, \& Computers, 36, 717-731. https://doi.org/10.3758/BF03206553

Reio, T. G., \& Callahan, J. L. (2004). Affect, curiosity, and socialization-related learning: A path analysis of antecedents to job performance. Journal of Business and Psychology, 19(1), 3-22. https://doi.org/10.1023/B:JOBU.0000040269.72795.ce

Richins, M. L. (1987). Media, materialism, and human happiness. in NA - Advances in Consumer Research eds. Melanie Wallendorf and Paul Anderson, Provo, UT: Association for Consumer Research, 14, 352-356.

Richins, M. L., \& Dawson, S. (1992). A consumer values orientation for materialism and its measurement: Scale development and validation. Journal of consumer research, 19(3), 303-316. https://doi.org/10.1086/209304

Rifkin, J. (2012). The third industrial revolution: How the internet, green electricity, and 3-d printing are ushering in a sustainable era of distributed capitalism. World Financial Review, 1 , 4052-4057.

Riskin, L. L. (1994). Mediator orientations, strategies and techniques. Alternatives to the High Cost of Litigation, 12(9), 111-114. https://doi.org/10.1002/alt.3810120904

Sethi, V., \& King, W. R. (1994). Development of measures to assess the extent to which an information technology application provides competitive advantage. Management Science, 40(12), 1601-1627. https://doi.org/10.1287/mnsc.40.12.1601

Shen, B., Jung, J., Chow, P. S., \& Wong, S. (2014). Co-branding in fast fashion: The impact of consumers' need for uniqueness on purchase perception. In Fashion branding and consumer behaviors, 101-112. Springer, New York, NY. https://doi.org/10.1007/978-1-4939-0277-4_7

Sheth, J. N., \& Talarzyk, W. W. (1972). Perceived instrumentality and value importance as determinants of attitudes. Journal of Marketing Research, 9(1), 6-9. https://doi.org/10.1177/002224377200900102 
Sheth, J. N., Newman, B. I., \& Gross, B. L. (1991). Why we buy what we buy: A theory of onsumption values. Journal of business research, 22(2), 159-170. https://doi.org/10.1016/0148-2963(91)90050-8

Simon, A., \& Honore, P. Y. L. (2012). Improving innovation and customer satisfaction through systems integration. Industrial Management \& Data Systems, 112(7), 1026-1043. https://doi.org/10.1108/02635571211255005

Smith, J. B., \& Colgate, M. (2007). Customer value creation: A practical framework. Journal $\begin{array}{llll}\text { of marketing } \quad \text { Theory } & \text { 7-23. }\end{array}$ https://doi.org/10.2753/MTP1069-6679150101

Solomon, M. R. (2007). Consumer behavior: Buying, having, and being, 7th ed., Paramount Publishing, Boston, MA.

Sun, H., \& Zhang, P. (2006). The role of moderating factors in user technology acceptance. International journal of human-computer studies, 64(2), 53-78. https://doi.org/10.1016/j.ijhcs.2005.04.013

Sweeney, J. C., \& Soutar, G. N. (2001). Consumer perceived value: The development of a multiple item scale. Journal of retailing, 77(2), 203-220. https://doi.org/10.1016/S0022-4359(01)00041-0

Teng, W., Lu, H. P., \& Yu, H. (2009). Exploring the mass adoption of third-generation (3G) mobile phones in Taiwan. Telecommunications Policy, 33(10-11), 628-641. https://doi.org/10.1016/j.telpol.2009.07.002

Thomé, K. M., Pinho, G. D. M., Fonseca, D. P., \& Soares, A. B. P. (2016). Consumers' luxury value perception in the Brazilian premium beer market. International journal of wine business research, 28(4), 369-386. https://doi.org/10.1108/IJWBR-09-2015-0043

Vanscoder, J. (2014). 3D printing as a tool for teaching and learning in STEAM education. In Proc. Society for Infor. Technol. \& Teacher Educ. Inter. Conf. 188-191.

Vickers, J. S., \& Renand, F. (2003). The marketing of luxury goods: An exploratory study-three conceptual dimensions. The Marketing Review, 3(4), 459-478. https://doi.org/10.1362/146934703771910071

Vigneron, F., \& Johnson, L. W. (2004). Measuring perceptions of brand luxury. The Journal of Brand Management, 11(6), 484-506. https://doi.org/10.1057/palgrave.bm.2540194

Warshaw, P. R. (1980). A new model for predicting behavioral intentions: An alternative to

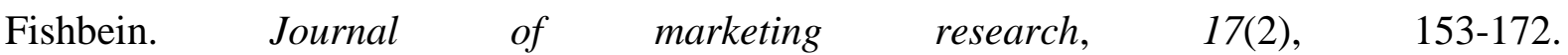
https://doi.org/10.1177/002224378001700201

Wedding (2013). The 3D selfie is born! Bride and groom create unique cake toppers that look EXACTLY like them using a printer. https://www.dailymail.co.uk/femail/article-2542765/Bride-groom-create-selfie-wedding-cake -topper-3D-printer.html, access time 2018/12/10 


\section{Macrothink}

International Journal of Human Resource Studies

ISSN 2162-3058 2019, Vol. 9, No. 2

Wei, R. (2001). From luxury to utility: A longitudinal analysis of cell phone laggards. $\begin{array}{lllll}\text { Journalism \& Mass Communication } & \text { Quarterly, 78(4), }\end{array}$ https://doi.org/10.1177/107769900107800406

Wiedmann, K. P., Hennigs, N., \& Siebels, A. (2007). Measuring consumers' luxury value perception: A cross-cultural framework. Academy of Marketing Science Review, 7(7), 333-361.

Wu, C. H. J., \& Liang, R. D. (2009). Effect of experiential value on customer satisfaction with service encounters in luxury-hotel restaurants. International Journal of Hospitality Management, 28(4), 586-593. https://doi.org/10.1016/j.ijhm.2009.03.008

Yanamandram, V., \& White, L. (2010). Are inertia and calculative commitment distinct constructs? An empirical study in the financial services sector. International Journal of Bank Marketing, 28(7), 569-584. https://doi.org/10.1108/02652321011085202

Zeelenberg, M., \& Pieters, R. (2004). Beyond valence in customer dissatisfaction: A review and new findings on behavioral responses to regret and disappointment in failed services. Journal of business Research, 57(4), 445-455.

Zhan, L., \& He, Y. (2012). Understanding luxury consumption in China: Consumer perceptions of best-known brands. Journal of Business Research, 65(10), 1452-1460.

\section{Appendix}

Monetary value [three items from Deng et al. (2010) to indicate the degree of users to pay from 3D printer, seven-point Likert type scale]

1. Using $3 \mathrm{D}$ printer will be unreasonable priced.

2. The price of using 3D printer will be expensive.

3. Using 3D printer will offer the value for money.

Functional value [four items from Deng et al. (2010) to indicate the degree of users to feel quality of 3D printer, seven-point Likert type scale]

1. Using 3D printer will be reliable.

2. Using 3D printer will have good functions.

3. Using 3D printer will fulfill my needs well.

4. Using 3D printer will be well fulfilled.

Individual value [four items from Deng et al. (2010) to indicate the degree of users' personal status from 3D printer, seven-point Likert type scale]

1. I will feel good when I use 3D printer.

2. I think using 3D printer will be enjoyable.

3. Using 3D printer will give me pleasure. 
4. I think using $3 \mathrm{D}$ printer will be interesting.

Social value [four items from Deng et al. (2010) to indicate the degree of users to feel the effect perceived by the individual in terms of from the ownership of the commodity from 3D printer, seven-point Likert type scale]

1. Using 3D printer will help me to feel acceptable.

2. Using 3D printer will make a good impression other people.

3. Using $3 \mathrm{D}$ printer will give me a sense of belongings to others users.

4. Using 3D printer will improve the way I am perceived.

Inertia [six items from authors Lee and Neale (2012) and Polites and Karahanna (2012) to evaluate the degree of people attitudinal propensity to maintain the current state, seven-point Likert type scale]

1. I never thought about switching to a new innovation, such as $3 \mathrm{D}$ printer.

2. I do not care about the functions of the new innovation, such as $3 \mathrm{D}$ printer.

3. I cannot be bothered to think about switching to a new innovation, such as 3D printer.

4. I will continue to use my existing utility even though I know that it is somewhat inefficient.

5. I will continue to use my existing utility even though I know that the utility quality is somewhat unstable.

6. I will continue to use my existing utility even though I know that it is not optimal.

Curiosity [three items from Huang (2003) and Moon and Kim (2010) to indicate the degree of people beliefs that having 3D printer will arouse their attentions, seven-point Likert type scale]

1. Knowing the 3D printer excites my curiosity.

2. The output of the $3 \mathrm{D}$ printer what I saw or heard increases me curious.

3. The application the 3D printer arouses my imagination.

Perceived need [three items from Teng et al. (2009) to indicate the degree of people to feel necessary in the daily life, seven-point Likert type scale]

1. There are lots innovations that fit I need.

2. The current innovation is important to me.

3. At present, I need 3D printer.

Intention to accept [three items from Teng et al. (2009) to indicate the degree of people to feel necessary in the daily life, seven-point Likert type scale] 
1. I intend to accept $3 \mathrm{D}$ printer.

2. I am willing to accept 3D printer.

3. I plan to accept 3D printer.

\section{Copyright Disclaimer}

Copyright for this article is retained by the author(s), with first publication rights granted to the journal.

This is an open-access article distributed under the terms and conditions of the Creative Commons Attribution license (http://creativecommons.org/licenses/by/4.0/). 